\title{
Redefining lactose as a conditional prebiotic
}

\author{
Andrew Szilagyi MD FRCPC
}

A Szilagyi. Redefining lactose as a conditional prebiotic. Can J Gastroenterol 2004;18(3):163-167.

Lactose in dairy products is maldigested by up to $70 \%$ to $75 \%$ of the world's population and many people may therefore suffer symptoms reminiscent of irritable bowel syndrome. As a result, most research to date has concentrated on ways of improving lactose tolerance to enhance dairy as a source of nutrition. However, research on other possible benefits of lactose and its maldigestion has lagged. In view of an exponential growth in the understanding of intestinal microfloral host interactions and the expanding therapeutical potential of probiotics, a reassessment of the role of lactose as a potential prebiotic in lactase nonpersistent subjects is required. Gibson and Roberfroid introduced the concept of prebiotics and outlined definitive requirements for such a compound. The present article examines scientific and clinical knowledge about the properties of lactose and argues that in lactase nonpersistent subjects, lactose qualifies as a prebiotic.

Key Words: Lactose; Lactose nonpersistance; Prebiotic

\section{Redéfinir le lactose comme un prébiotique conditionnel}

De $70 \%$ à $75 \%$ de la population mondiale digèrent mal le lactose contenu dans les produits laitiers, et par conséquent, de nombreuses personnes peuvent souffrir de symptômes rappelant ceux du syndrome du côlon irritable. Ainsi, jusqu'à présent, la plupart des recherches ont porté sur les moyens d'améliorer la tolérance au lactose pour accroitre le recours aux produits laitiers comme sources de nutrition. Cependant, les recherches sur d'autres bienfaits potentiels du lactose et sur sa mauvaise digestion ont piétiné. Étant donné la croissance exponentielle de la compréhension des interactions de l'hôte de la microflore intestinale et le potentiel thérapeutique croissant des probiotiques, il faut réévaluer le rôle du lactose comme prébiotique potentiel chez les sujets non persistants à la lactase. Gibson et Roberfroid ont créé le concept de prébiotiques et ont énoncé les exigences absolues d'un tel agent. Le présent article porte sur les connaissances scientifiques et cliniques à l'égard des propriétés du lactose et avance que chez les sujets non persistants à la lactase, le lactose se définit comme un prébiotique.
T actose maldigestion and intolerance was initially described Lin the 1960s. Symptoms of gas, cramps, bloating and diarrhea resembled those sustained in irritable bowel syndrome (IBS), and for the first time a possible biochemical explanation for this elusive condition became available (1). The notion that lactose intolerance is responsible for IBS has captured the public imagination and spawned the introduction of lactosefree products and digestive enzymes. The extent and significance to the public interest of this association is attested to by the listing of over 72,000 internet sites on lactose intolerance. However, the prevailing view was perhaps based on insufficient information, and other possible roles for lactose were not considered.

Our thinking about the role of this disaccharide needs to be re-evaluated in view of the exponential growth of knowledge in the last 10 to 15 years about pathogen-host, and commensal intestinal floral-host, interactions. Bacteria have evolved mechanisms which disrupt defensive tactics of host mucosal membranes, stimulate electrolyte secretory pumps and incite the inflammatory cytokine sequence (2). Other bacteria, most of which are (but not exclusively) lactic acid producing bacteria, not only can interfere with pathogen mucosal attachment but also inhibit the effect of pathogens and other potential pathogens residing in the commensal flora (3-5).
In parallel with the understanding of bacterial and host communications, the medical use of probiotics has emerged as a plausible therapeutic option (6). There is reasonably good evidence of therapeutic probiotic benefit with gastroenteritis (especially rotavirus) $(7,8)$ recurrence of antibiotic-associated diarrhea (9), pouchitis $(10,11)$ and emerging studies with inflammatory bowel diseases (IBD) $(12,13)$.

Another area of advance has been made in the field of prebiotics, which is defined by Gibson and Roberfroid (14) as, "a non digestible food ingredient that beneficially affects the host by selectively stimulating the growth and/or activity of one or a limited number of bacteria in the colon and thus improves host health." Table 1 lists the characteristics of prebiotics as defined by these authors. Table 2 lists a number of prebiotics, most of which are manufactured or derived from foods. It should be noted that at least three (transgalacto-oligosaccharides, fucooligosaccharides and lactulose) are derived from lactose. Among these sugars, perhaps lactulose (galactose fructose) resembles lactose the closest (15-17).

Lactulose is probably the first manufactured prebiotic. Originally, it was used for constipation and the treatment of hepatic encephalopathy (17). Subsequently, other benefits were ascribed to lactulose (18). Lactulose was slowly recognized as a prebiotic because many of its effects are associated

McGill University School of Medicine, Division of Gastroenterology, Department of Medicine, The Sir Mortimer B, Davis-Jewish General Hospital, Montreal, Quebec

Correspondence and reprints: Dr Andrew Szilagyi, The Sir Mortimer B Davis-Jewish General Hospital, 3755 Cote St Catherine Road, Room G-327, Montreal, Quebec H3T 1E2. Telephone 514-340-8144, fax 514-340-8282, e-mail aszilagy@gas.jgh.mcgill.ca Received for publication September 24, 2003. Accepted February 4, 2004 
with altered metabolism by resident flora and with expansion of selective, putatively beneficial, bacteria of Bifidobacteria species $(17,18)$.

In this article I will argue that the original lactose in lactase insufficient subjects exerts prebiotic effects. This is a composite hypothesis based on the observation and thinking of a number of different groups $(18,24)$. The objective is to fit lactose point by point into Gibson and Roberfroid's (14) definition of a prebiotic.

\section{CHARACTERISTICS OF PREBIOTICS}

\section{Nonhydrolysis and nonabsorption in the upper gastroin-} testinal tract

While all animals and humans are born with the ability to digest lactose, intestinal lactase levels decrease after weaning in all except approximately $25 \%$ to $30 \%$ of humans. This human dichotomy is achieved through genetic control, mostly at the transcription and some at the translational level (25). Lactase persistence (LP) is dominant while lactase nonpersistence (LNP) is autosomally inherited. Most genetically ordained LNP subjects lose approximately $90 \%$ of intestinal lactase in early to midchildhood (depending on ethnicity) $(18,26)$. While in animals lactase may be induced by continued consumption of lactose, in humans this phenomenon has not been observed (27). As a result, $70 \%$ to $75 \%$ of the population is left with a permanent loss of lactase; because of this genetic dichotomy, it is likely that lactose consumption has a clear relationship with LNP status. In general, LNP subjects consume less lactose. Proof of nonhydrolysis in LNP subjects can be measured with a variety of tests and also may result in uncomfortable symptoms (18). However, it has been clearly shown that they can tolerate $250 \mathrm{~mL}$ to $500 \mathrm{~mL}$ of milk (approximately $25 \mathrm{~g}$ lactose) without any difficulty $(28,29)$. More likely, altered consumption of lactose is affected by cultural practices. The inability to digest lactose in the face of continued consumption sets up conditions for possible prebiotic effects which could therefore be considered conditional. Whether massive doses of lactose in LP subjects could potentially exert a spillover effect similar to resistant starch has not been formally studied.

\section{Selectivity of flora, growth and metabolic activation}

The industrial aim of designing prebiotics is to selectively feed putative beneficial bacteria in the lower intestine. The current gold standard beneficial of targeting are species of Bifidobacteria. However, many other bacteria may exert beneficial effects and in fact controlled trials with probiotics for gastrointestinal diseases show proof of efficacy for Lactobacillus GG (rotaviral gastroenteritis (8) and relapse of antibioticassociated diarrhea) (9), Escherichia coli strain nissle (a nonpathogenic Escherichia coli) in ulcerative colitis (30) and a mixture of Lactobacillus, Bifidobacteria and one strain of Streptococcus salivarius subspecies thermophilus (VSL3, VSL Pharmaceuticals Inc, USA) in pouchitis $[10,11]$ and IBD [13]).

There are few studies which examine fecal bacterial effects of chronic lactose consumption in LNP subjects. However, there are laboratory and clinical studies which circumstantially suggest that desired targeted bacteria, Bifidobacteria and Lactobacillus are indeed stimulated to grow and are metabolically activated.

There are numerous lactose fermenting species of bacteria in the lower intestine. However, Hill (20) hypothesized that lactic acid bacteria are selectively stimulated by chronic lactose feeding. Indeed, a study by Ito and Kimura (22) showed that despite the ability to ferment lactose, Bacteroides and Clostridia perfringens $\left(\log _{10}\right)$ colony counts decreased in the stool of LNP volunteers who were given $15 \mathrm{~g} /$ day of lactose. Colony counts of Lactobacillus significantly increased along with counts of Staphylococcus, Candida and Enterococci. There was also a nonsignificant increase in Bifidobacteria counts. However, because total bacteria also decreased, there was a significant proportional increase in Bifidobacteria ratios (22).

As stated, lactulose is quite similar to lactose, and interestingly a bacterial profile in response to chronic $3 \mathrm{~g} /$ day lactulose feeding also led to decreased Bacteroides and $\mathrm{C}$ perfringens populations (31). Bifidobacteria significantly increased $(31,32)$ while Lactobacillus significantly decreased (31). However an earlier study in cirrhotics did show increased fecal Lactobacilli counts (33). While these results are not identical, they show that adaptation occurs to either lactose or lactulose resulting in elevation of desired target bacteria (note that lactulose is an accepted prebiotic).

The clinical features of colonic bacterial adaptation after prolonged sugar consumption is distinguished by diminished measured breath hydrogen and, likely, improved symptoms on rechallenge with standard doses of the sugar in question $(23,34)$. This reduction was initially reported by Perman et al (35) to be due to fecal acidification induced by metabolism of the test sugar (lactulose) to short chain fatty acids (mainly acetate). Fecal $\mathrm{pH}$ decreased to below $\mathrm{pH} 6$ in volunteers and in vitro infusion studies on feces showed that fermentation was inhibited at this low $\mathrm{pH}$. Perman et al did not measure fecal bacteria or fecal $\beta$-galactosidase. Hertzler and Savaiano (23) were able to demonstrate improved lactose intolerance in LNP volunteers using increased lactose doses up to $1 \mathrm{~g} /$ day over 16 days. The adaptation was accompanied by the expected reduced breath hydrogen and as well a threefold increase in fecal $\beta$-galactosidase. In fecal infusion studies (while maintaining a near neutral $\mathrm{pH}$ ), they were able to show that hydrogen production decreased while infused lactose consumption was completed (36). In another in vitro study, Jiang and Savaiano (37) showed that when $\mathrm{pH}$ was held constant there was complete consumption of infused lactose up to $25 \mathrm{~g}$. However, infusion of $50 \mathrm{~g}$ overwhelmed and diminished the quantity of lactose consumption. This in vitro system was facilitated by the addition of Lactobacilli but only for the first of seven days. In vitro $\beta$-galactosidase increased 20 -fold. Another study confirmed, just as Perman et al (35) had shown, that in vitro lactose consumption was $\mathrm{pH}$ dependent. At near neutral $\mathrm{pH}$, but not low $\mathrm{pH}$, the addition of Bifidobacteria in vitro facilitated lactose consumption throughout a period of $72 \mathrm{~h}$. Nevertheless, the authors postulated that the healthy colon absorption of short chain fatty acids and the secretion of bicarbonate likely compensated somewhat for the disaccharideinduced decrease in $\mathrm{pH}$ (38).

The demonstration that chronic lactulose feeding in subjects improves parameters of lactose intolerance suggests again that similar mechanisms exist between the probable prebiotic (lactulose) and the contender, lactose (39). Interestingly I also found a threefold increase in fecal $\beta$-galactosidase at a dose of $10 \mathrm{~g}$ twice daily of lactulose. The maximum single dose of lactose digested by remaining intestinal lactase in most LNP subjects is still unclear. However, in Japanese subjects this value may be $10 \mathrm{~g}$ (Dr T Oku, Siebold University, Nagasaki, Japan, 
TABLE 1

\section{Characteristics of prebiotics as defined by Gibson and Roberfroid (14)}

It must be neither hydrolyzed nor absorbed in the upper part of the gastrointestinal tract.

It must be a selective substrate for one or a limited number of beneficial bacterial commensal to the colon which are stimulated to grow and/or are metabolically activated.

It must consequently be able to alter the colonic flora in favour of a healthier composition.

It must induce luminal or systemic effects that are beneficial to the host health.

personal communications). The equivalent of the lactulose dose to lactose may therefore be 18 or $19 \mathrm{~g}$ twice daily or a little over $500 \mathrm{~mL}$ of milk each day. Because fecal $\beta$-galactosidase levels in vivo seem to remain elevated to two to three times baseline levels $(23,34,39)$ an interesting conclusion may be drawn. In the study by Hertzler and Savaiano (23) all subjects on rechallenge with lactose became negative on hydrogen excretion on $1 \mathrm{~g} / \mathrm{kg} /$ day adapting dose; that is, their tests no longer showed that genetically LNP subjects were maldigesters. In the present study one-third of the subjects no longer registered LNP status on rechallenge. In addition, there was a reasonably good correlation between estimated daily grams of ingested lactose using a seven and three day recall interview and initial results of summed breath hydrogen (39). No such correlation between dietary lactose and fecal $\beta$-galactosidase was observed either in our study or another of Suarez and Savaiano (40) possibly because fecal enzyme elevation was similar despite the different oral doses used. This observation suggests that perhaps the bacterial species expansion is limited and increasing doses improve metabolism to ensure a homogeneous population effect. In other words, there is a maximum dose which maximizes metabolism of the sugar in any individual. This is also corroborated by the in vitro study of Jiang and Savaiano (37). Although there is a further need to explore the fecal bacterial effects of chronic lactose ingestion, with more up to date microbiological methods, the interpretation of these aforementioned experiments satisfy the second criteria of Gibson and Roberfroid.

\section{Alteration of colonic flora in favour of a healthier composition}

This requirement of the definition is somewhat vague because there is only circumstantial and early evidence that floral composition may be disease protective. However, one condition, (hepatic encephalopathy [PSE]), is intimately connected with colonic microfloral metabolism and, likely, specific groups of bacteria. Regardless of which hypothesis of causation of PSE is considered, treatment is directed toward the alteration of colonic microflora to improve the condition (41). Change in colonic flora composition may be effected by antibiotics neomycin (42), vancomycin (43) and metranidazole (44), or lactulose (24).

Antibiotics presumably reduce the numbers of offending bacteria (mainly putrefactive species) but may also reduce the numbers of protective species. Lactulose on the other hand is more selective. While the exact mechanism of action is still debated, the likely effect is the reduction of ammonia production with enhanced nitrogen consumption by specific
TABLE 2

Prebiotic compounds

\begin{tabular}{ll}
\hline Inulin & Present in onions, leeks, hickory \\
Fructo-oligosaccharides & Product of hydrolysis inulin \\
Isomalto-oligosaccharides & Present in foods \\
Fuco-oligosaccharides & $\begin{array}{l}\text { May be present in breast milk } \\
\text { Formed from lactose }\end{array}$ \\
Trans-galacto-oligosaccharides & $\begin{array}{l}\text { Manufactured from lactose by } \\
\text { bacterial action } \\
\text { Lactulose }\end{array}$ \\
\hline
\end{tabular}

bacteria $(24,45,46)$. Moreover, the PSE therapeutic effect is also reproduced by feeding Enterococci faecium (47) and possibly by other Gram-positive anaerobes since these also produce less ammonia $(31,32,46)$. As stated above, both Bifidobacteria and Lactobacillus seem to be quantitatively expanded by lactulose.

More than 23 years ago Uribe et al (48) showed that in LNP Mexican subjects lactose was more efficient in improving PSE than neomycin. They subsequently showed microbial alteration in fecal flora similar to lactulose as a result of lactose therapy (49). Lactitol (a derivative of lactulose) was also shown to reproduce the PSE therapeutic effect (50). Nevertheless, one can argue that based on the aforementioned microfloral alteration, lactose in LNP subjects promotes a 'healthier' flora in cirrhosis, thus satisfying the third criteria of Gibson and Roberfroid.

\section{Beneficial effects to host health}

Improvement of hepatic encephalopathy and lactose intolerance (a commonly touted benefit of probiotics in yogurt) are enough to qualify lactose for this section. However, the possible benefits of lactose may be further extended by hypothesizing that the similarity of this natural disaccharide to lactulose may also mimic some of the benefits attributed to the latter. Lactulose has been shown to impact on infections of the gastrointestinal tract (51-53), it has been shown to affect surrogate fecal markers of carcinogenesis (54) and has even been proposed for prevention of IBD (55). Studies in these areas using lactose have been lagging.

The relevance of redefining lactose as a prebiotic Lactose seems to fit the definition of Gibson and Roberfroid, and therefore it can be considered a conditional prebiotic in LNP subjects.

\section{RATIONALE FOR REDEFINING LACTOSE}

Why in particular is it important to recognize lactose as a conditional prebiotic? Its relevance may be linked with the large number of people with LNP status who still consume some lactose. It may therefore represent the most widely used natural prebiotic, and can be used as a testable marker to examine whether the genetic dichotomy of LP/LNP status impacts on disease pathogenesis.

The impact of lactose consumption or failure of consumption in LNP subjects could add a different perspective on early development and pathogenesis of a number of diseases. Possibly the crude biological test for colonic adaptation could be used to functionally assess the level of protective status of intestinal microflora in a variety of conditions. Although 
confirmation is required I recently provided physiological evidence using the adaptation concept to support the notion that IBD may be an endogenous 'probiotic' deficient disease (56) and thus support the therapeutic role of exogenous probiotics. It also raises a testable hypothesis regarding early pathogenic events in some lower intestinal diseases. The notion of altered bacterial flora in pseudo membranous colitis and emergence of Clostridium difficile as a cause is now accepted and is largely contributed to by antibiotics (57). In this event, the possible acute loss of protective flora leads to a reasonably clear outcome. However, what if protective bacterial loss occurs for unknown reasons (diet, antibiotics in feeds, food additives, etc) over several weeks, months or years? In this paradigm IBD could represent disease with intermediate time of loss of endogenous 'probiotics' and perhaps colon cancer as a long term consequence. The observed increased risk of cancer in IBD could potentially be facilitated. An obvious question in these scenarios is what role might LNP status play in early pathogenesis. Would lactose consuming LNP subjects be equally at risk as lactose nonconsuming LNP/LP subjects? What is the role of lactose consumption in floral maintenance in LNP populations?

For example, my colleagues and I are currently reassessing results of studies examining the relationship between dairy consumption and colorectal neoplasms (manuscript in preparation). There are conflicting outcomes of meta analyses on this subject (58-60). However, there is a suggestion that if the

\section{REFERENCES}

1. Scrimshaw NS, Murray EB. The acceptability of milk and milk products in populations with high prevalence of lactose intolerance. Am J Clin Nutr 1988;48(Suppl 4):1079-159.

2. Berkes J, Viswanathan VK, Savkovic SD, Hecht G. Intestinal epithelial responses to enteric pathogens: effects on the tight junction barrier, ion transport and inflammation. Gut 2003;52:439-51.

3. Heyman M, Menard S. Probiotic microorganisms: How they affect intestinal pathophysiology. Cel Mol Life Sci 2003;59:1151-65.

4. Madsen K, Cornish A, Soper P, et al. Probiotic bacteria enhance murine and human intestinal epithelial barrier function. Gastroenterology 2001;121:580-91.

5. Neish AS, Gewirtz AT, Zeng H, et al. Prokaryotic regulation of epithelial responses by inhibition of IkappaB-alpha ubiquination. Science 2000;289:1560-3.

6. Marteau PR, de Vrese M, Cellier CJ, Schrezenmeir J. Protection from gastrointestinal diseases with the cue of probiotics. Am J Clin Nutr 2001;73(Suppl 2):430S-436S.

7. Heyman M. Effect of lactic acid bacteria on diarrheal diseases. J Am Coll Nutr 2000;19:137S-146S.

8. Huang JS, Bousvaros A, Lee JW, Diaz A, Davidson EJ. Efficacy of probiotic use in acute diarrhea in children. A meta-analysis. Dig Dis Sci 2002;47:2625-634.

9. D'Souza AL, Rajkumar C, Cooke J, Bulpitt CJ. Probiotics in prevention of antibiotic associated diarrhea: Meta-analysis. Br Med J 2002;324:1361-64.

10. Gionchetti P, Rizzello F, Venturi A, et al. Oral bacteriotherapy as maintenance treatment in patients with chronic pouchitis: A double-blind, placebo-controlled trial. Gastroenterology 2000;119:305-9.

11. Gionchetti P, Zizzello F, Helwig U, et al. Prophylaxis of pouchitis onset with probiotic therapy, a double-blind, placebo-controlled trial. Gastroenterology 2003;124:1202-9.

12. Hamilton-Miller JMT. A review of clinical trials of probiotics in the management of inflammatory bowel disease. Infect Dis Rev 2001;3:83-7.

13. Fedorak RN, Gionchetti P, Campieri M, et al. VSL3 probiotic mixture induces remission in patients with active ulcerative colitis. Gastroenterology 2003;124:A377. (Abst)

14. Gibson GR, Roberfroid MB. Dietary modulation of the human colonic microbiota: Introducing the concept of prebiotics. J Nutr 1995;125:1401-12. outcome of studies on the subject are reanalysed, by including the frequency of LNP status in the country of origin, then discrepancies in these meta analyses may be explained. As such future dietary studies on dairy and colorectal neoplasms could incorporate measured LNP status as a variable.

\section{SUMMARY}

This article summarizes data which then are used to argue that lactose should be considered as a conditional prebiotic. It is emphasized that in the context of a prebiotic, lactose must naturally exert an effect on lower intestinal microflora. Therefore, the consumption or failure to do so might exert subtle protective or permissive pathogenic influences toward a number of diseases. Therefore, the division of populations along LP/LNP status may offer an opportunity to study disease patterns related to bacterial flora.

It is suggested that studying the potential influences of genetic dichotomy of lactase status could be modeled after the Framingham $(61,62)$ or Nurses Health Study $(63)$ in which LP or LNP status is determined at the beginning and participants are periodically evaluated.

ACKNOWLEDGEMENT: I wish to thank Ms Blanka Glowacki for helping to retrieve articles and Ms Florence Lurie for secretarial services.
15. Onishi N, Yamashiro A, Yokozeki K. Production of galactooligosaccharide from lactose by Sterigmatomyces elviae CBS8119. Appl Environ Microbiol 1995;61:4022-5.

16. Newburg DS. Do the binding properties of oligosaccharides in milk protect human infants from gastrointestinal bacteria? J Nutr 1997;127(Suppl 5):980S-4S.

17. Schumann C. Medical, nutritional and technological properties of lactulose. An update. Eur J Nutr. 2002;41(Suppl 1):I17-25.

18. Szilagyi A. Lactose-a potential prebiotic. Aliment Pharmacol Ther 2002;16:1591-602.

19. International agency. Dietary fibre, transit-time, faecal bacteria, steroids and colon cancer in two Scandinavian populations. Lancet 1977;1:207-11.

20. Hill MJ. Bacterial adaptation to lactase deficiency. In: Milk Intolerances and Rejection. Karger: Basel, 1983;22-26.

21. Villar J, Kestler E, Castillo P, Juarez A, Menendez R, Solomons NW. Improved lactose digestion during pregnancy: A case of physiologic adaptation. Obstet Gynecol 1988;71:697-700.

22. Ito M, Kimura M. Influence of lactose on faecal microflora in lactose maldigesters. Microbial Ecol Health Dis 1993;6:73-6.

23. Hertzler SR, Savaiano DA. Colonic adaptation to daily lactose feeding in lactose maldigesters reduces lactose intolerance. Am J Clin Nutr 1996;64:232-6.

24. Clausen MR, Mortensen PB. Lactulose disaccharides and colonic flora. Clinical consequences. Drugs 1997;53:930-42.

25. Lloyd ML. The regulation of lactase expression in adult life. In: Aurichio S, Semenza G eds. Common Food Intolerances 2. Milk in human nutrition and adult type hypolactasia. Karger: Basel, 1993:24-31.

26. Wang Y, Harvey CB, Hollox EJ, et al. The genetically programmed down-regulation of lactase in children. Gastroenterology 1998;114:1230-6.

27. Gilat T, Russo S, Gelman-Malachi E, Aldor TA. Lactase in man: A nonadaptable enzyme. Gastroenterology 1972;62:1125-7.

28. Suarez FL, Savaiano D, Arbisi P, Levitt MD. Tolerance to the daily ingestion of two cups of milk by individuals claiming lactose intolerance. Am J Clin Nutr 1997;65:1502-6.

29. Vesa TH, Korpela RA, Sahi T. Tolerance to small amounts of lactose in lactose maldigestion. Am J Clin Nutr 1996;64:197-201.

30. Kruis W, Schutz E, Fric P, Fixa B, Judmaier G, Stolte M. Doubleblind comparison of an oral Escherichia coli preparation and 
mesalanine in maintaining remission of ulcerative colitis. Aliment Pharmacol Ther 1997;11:853-8.

31. Terada A, Hara H, Kataoka M, Mitsuoka T. Effect of lactose on composition and metabolic activity of the human faecal flora. Microbiol Ecol Health Dis 1992;5:43-50.

32. Bouhnik Y, Attar A, Telotte A, Franchisseur C, Riottot M, Dyard F. Lactulose ingestion increases fecal bifidobacterial counts in healthy humans. Gasroenterology 1999;116:A541. (Abst)

33. Riggio O, Varriale M, Tertore GP, et al. Effect of lactitol and lactulose administration on the fecal flora in cirrhotic patients. J Clin Gastroenterol 1990;12:433-6

34. Flourie B, Briet F, Florent C, Pellier P, Maurel M, Rambaud JC. Can diarrhea induced by lactulose be reduced by prolonged ingestion of lactulose? Am J Clin Nutr 1993;58:369-75.

35. Perman JA, Modler S, Olson AC. Role of $\mathrm{pH}$ in production of hydrogen from carbohydrates by colonic bacterial flora. Studies in vivo and in vitro. J Clin Invest 1981;67:643-50.

36. Hertzler S, Savaiano DA, Levitt MD. Fecal hydrogen production and consumption measurements. Response to daily lactose ingestion by lactose maldigesters. Dig Dis Sci 1997;42:348-53.

37. Jiang T, Savaiano DA. In vitro lactose fermentation by human colonic bacteria is modified by lactobacillus acidophilus supplementation. J Nutr 1997;127:1489-95.

38. Jiang T, Savaiano DA. Modification of colonic fermentation by bifidobacteria and $\mathrm{pH}$ in vitro impact on lactose metabolism shortchain fatty acid, lactate production. Dig Dis Sci 1997;42:2370-7.

39. Szilagyi A, Rivard J, Fokeeff K. Improved parameters of lactose maldigestion using lactulose. Dig Dis Sci 2001;46:1509-19.

40. Suarez FI, Savaiano DA. Lactose digestion and tolerance in adult and elderly Asian Americans. Am J Clin Nutr 1994;59:1021-4.

41. Odeh M. Endotoxin and tumor necrosis factor-alpha in the pathogenesis of hepatic encephalopathy. J Clin Gastroenterol 1994;19:146-53.

42. Dawson AM, McLaren J, Sherlock S. Neomycin in the treatment of hepatic coma. Lancet 1957;2:1263-8.

43. Tarao K, Ikeda T, Hayashi K, et al. Successful use of vancomycin hydrochloride in the treatment of lactulose resistant chronic hepatic encephalopathy. Gut 1990;31:702-6.

44. Morgan MH, Read AE, Speller DCE. Treatment of hepatic encephalopathy with metronidazole. Gut 1982;23:1-7.

45. Mortensen PB. The effect of oral-administered lactulose on colonic nitrogen metabolism and excretion. Hepatology 1992;16:1350-6.

46. Vince AJ, Burridge SM. Ammonia production by intestinal bacteria: The effects of lactose, lactulose and glucose. J Med Microbiol 1980;13:177-91.

47. Loguercio C, Abbiati R, Renaldi M, Romano A, Del Vecchio B, Coltorti M. Long-term effects of Enterococcus faecium SF68 versus lactulose in the treatment of patients with cirrhosis and grade 1-2 hepatic encephalopathy. J Hepatol 1995;23:39-46.

48. Uribe M, Marquez MA, Garcia-Ramos G, Escobedo V, Murillo H, Guevara L, Lisker R. Treatment of chronic portal-systemic encephalopathy with lactose in lactase deficient patients. Dig Dis Sci 1980;25:924-8.

49. Uribe-Esquivel M, Moran S, Poo JL, Munoz RM. In vitro and in vivo lactose and lactulose effects on colonic fermentation and portal-systemic encephalopathy parameters. Scand J Gastroenterol (Suppl) 1997;222:49-52.

50. Lanthier PL, Morgan MY. Lactitol in the treatment of chronic hepatic encephalopathy: an open comparison with lactulose. Gut 198;26:415-22.

51. Levine MM, Hornick RB. Lactulose therapy in Shigella carrier state and acute dysentry. Antimicrob Agents Chemother $1975 ; 81: 581-4$

52. Hanson HB, Barkenius G, Gonberg S, Juhlin I. Controlled comparison of nalidixic acid or lactulose with placebo in shegellosis. Scand J Infect Dis 1981;13:191-3.

53. Bovee-Oudenhoven IM, Termont DS, Heidt PJ, Van der Meer R. Increasing the intestinal resistance of rats to the invasive pathogen salmonella enteritidis: additive effects of dietary lactulose and calcium. Gut 1997;40:497-504.

54. Van Berge Henegouwen GP, Van der Werf SD, Ruben AT. Effect of long term lactulose ingestion on secondary bile salt metabolism in man: Potential protective effect of lactulose in colonic carcinogenesis. Gut 1987;2:675-80.

55. Liao W, Cui XS, jin H-Y, Floren CH. Lactulose-a potential drug for the treatment of inflammatory bowel disease. Med Hypotheses 1994:43:234-8.

56. Szilagyi A, Rivard J, Shrier I. Diminished efficacy of colonic adaptation to lactulose occurs in patients with inflammatory bowel disease in remission. Dig Dis Sci 2002;47:2811-22.

57. Hurley BW, Nguyen CC. The spectrum pf pseudomembranous enterocolitis and antibiotic-associated diarrhea. Arch Intern Med 2002;162:2177-84.

58. Bergsma-Kadijk JA, van't Veer P, Kampman E, Burema J. Calcium does not protect against colorectal neoplasia. Epidemiology 1996;7:590-7.

59. Yoon H, Benamouzig R, Little J, Francois-Collange M, Tome D. Systematic review of epidemiological studies on meat, dairy products and egg consumption and risk of colorectal adenomas. Eur J Cancer Prev 2000;9:151-64.

60. Norat T, Riboli E. Dairy products and colorectal cancer. A review of possible mechanisms and epidemiological evidence. Eur J Clin Nutr 2003;57:1-17.

61. McKeown NM, Meigs JB, Liu S, Saltzman E, Wilson PW, Jacques PF. Carbohydrate nutrition, insulin resistance, and the prevalence of the metabolic syndrome in the Framingham Offspring Cohort. Diabetes Care 2004;27:538-46.

62. Millen BE, Quatromoni PA, Nam BH, et al. Dietary patterns, smoking, and subclinical heart disease in women: Opportunities for primary prevention from the Framingham nutrition studies. J Am Diet Assoc 2004;104:208-14.

63. Liu S, Manson JE, Stampfer MJ, et al. Whole grain consumption and risk of ischemic stroke in women: A prospective study. JAMA 2000;284:1534-40. 


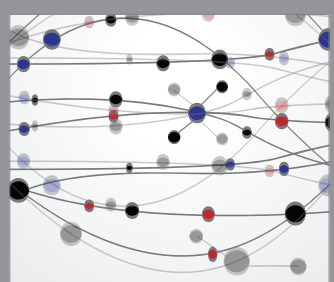

The Scientific World Journal
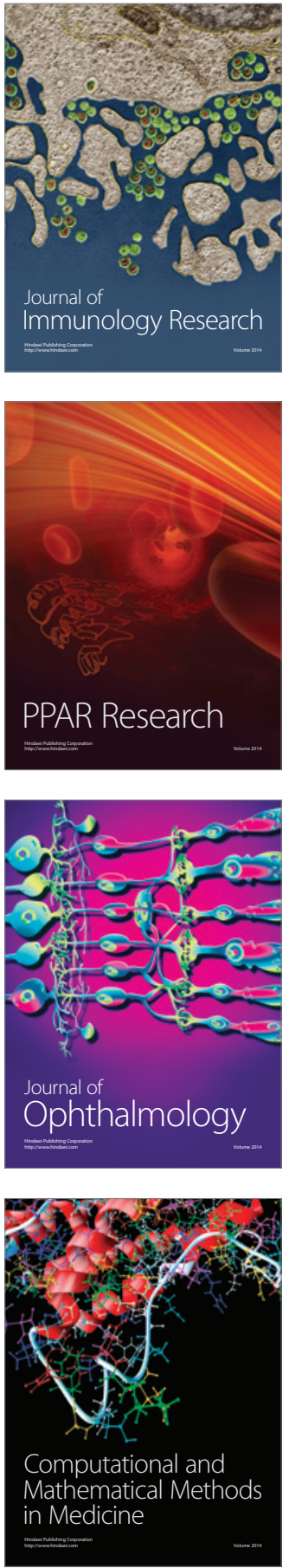

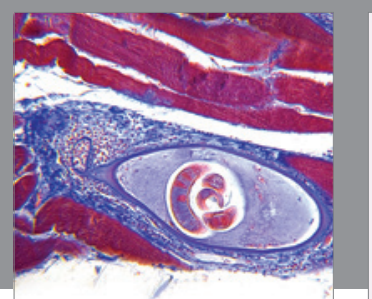

Gastroenterology Research and Practice

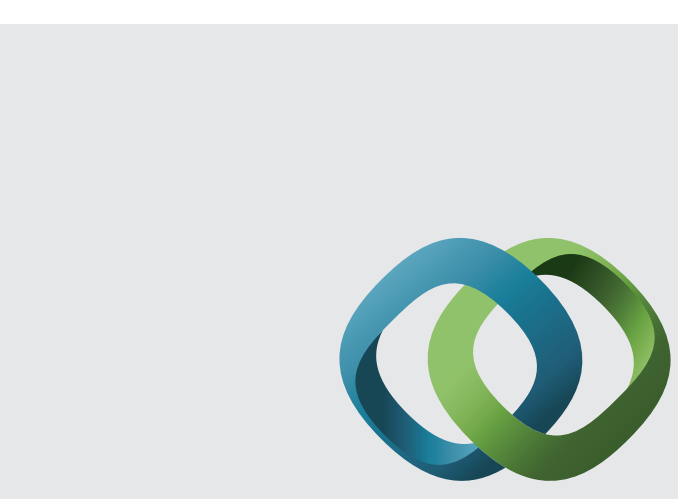

\section{Hindawi}

Submit your manuscripts at

http://www.hindawi.com
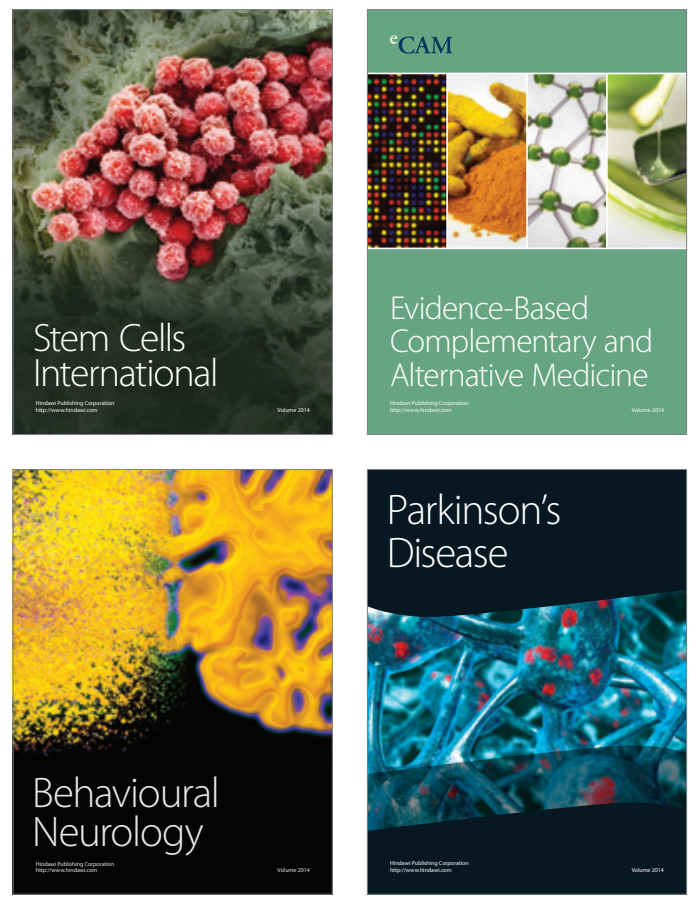
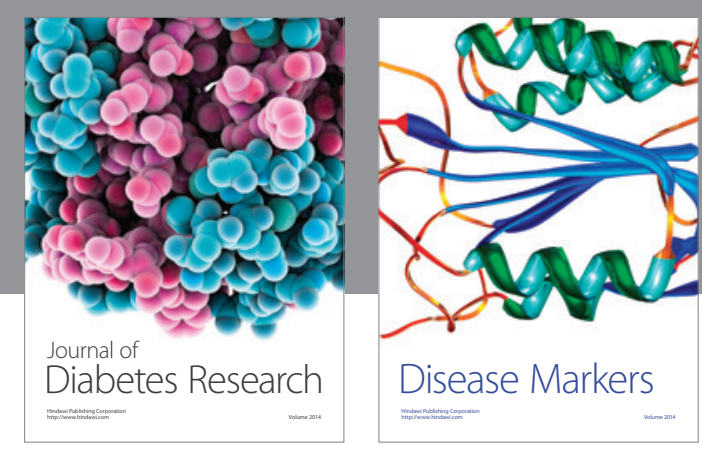

Disease Markers
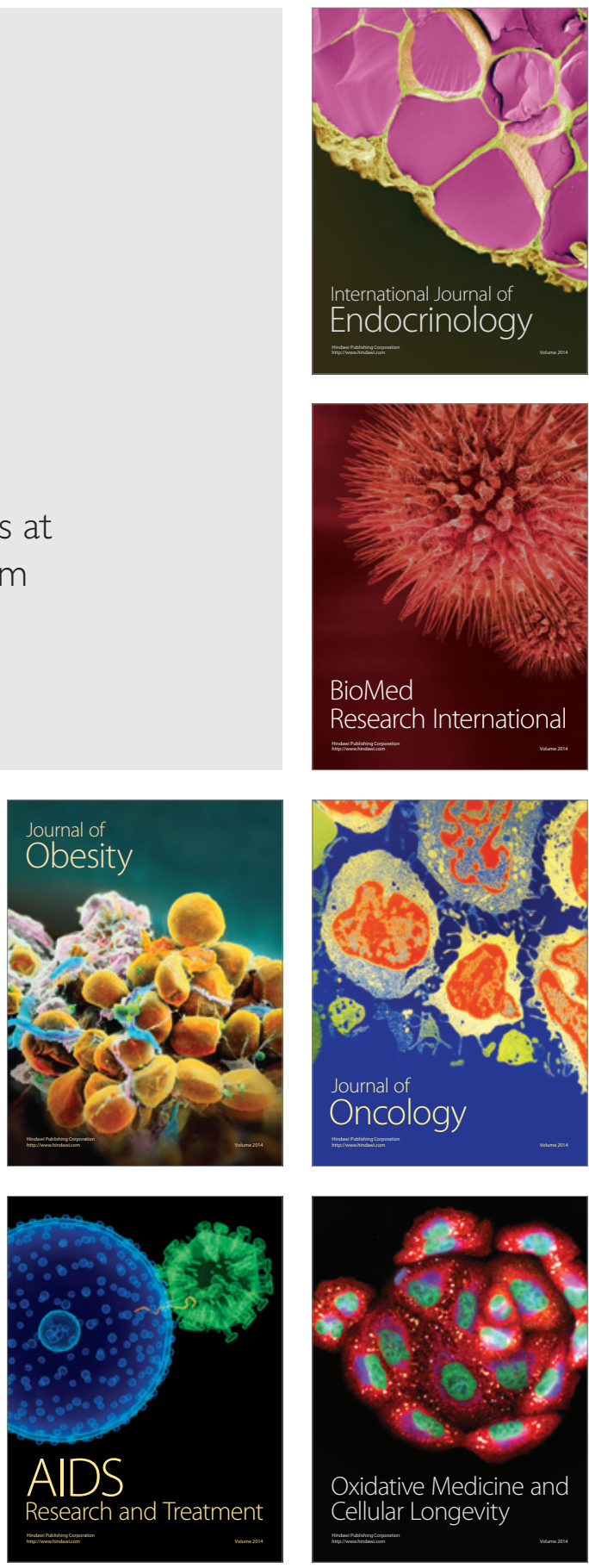